Selcuk Journal of Agriculture and Food Sciences

http://sjafs.selcuk.edu.tr/sjafs/index

Research Article
SJAFS

(2021) 35 (3), 187-193

e-ISSN: 2458-8377

DOI:10.15316/SJAFS.2021.247

\title{
Application of Raw Rock Phosphate and Earthworm (Lumbricus terrestris L.) On The Development and Nutrient Content of Corn Plant
}

iD Emel ATMACA*

*Selçuk University, Faculty of Agriculture, Department of Soil Science and Plant Nutrition, Konya, Turkey

\begin{tabular}{l}
\hline ARTICLE INFO \\
\hline Article history: \\
Received date: 12.07 .2021 \\
Accepted date: 24.08 .2021 \\
\hline
\end{tabular}

Keywords:

Phosphate rock

Earthworm

Corn plant

Phosphate solubility

\begin{abstract}
Due to the fact that phosphate rock is water insoluble, the interaction of macro and micro organisms in the soil becomes important to increase its solubility. A study in the soil to investigate the effects of raw rock phosphate and earthworm castings application on the development and nutrient element content of corn plant was carried out in four frequency series as a greenhouse trial. To that end, 0-5-10-15-20-25-30-35 and $40 \mathrm{~kg} \mathrm{da}^{-1}$ raw rock phosphate (15\%) and earthworms (Lumbricus terrestris L.) were added to the soil in $\mathrm{P}_{2} \mathrm{O}_{5}$ application dose. Only the same does of raw rock phosphate was added to the other doses. Nutrient element content of the corn plant (N, P, K, Ca, Mg, Fe, Cu, Mn and $\mathrm{Zn}$ ) in the pots with raw rock phosphate and earthworm castings application generally increased in comparison with the other pots which were not applied earthworm. According to the data obtained in the study, the effect of earthworm and different level of raw rock phosphate on the growth of corn plant was found statistically significant $(\mathrm{p}<0.05)$.
\end{abstract}

\section{Introduction}

Phosphorus castings are obtained by burning natural rock phosphate chemically or grinding finely. The use of phosphorus castings is increasing day by day because the amount of beneficial phosphorus for plants is low in the soil, so the phosphorus reserves used to produce phosphorus castings are gradually decreasing (Gahoonia et al. 1999). Raw phosphate or rock phosphate, known as phosphate rock, is the parent material of phosphorus castings. Rock phosphates are generally in apatite form in the nature and they are named as carbonate apatite, flourapatite, hydroxy apatite and sulphate apatite in terms of anion and cation in its content; the most commonly used one is flourapatite (Köleli and Kantar 2005).

Earthworms have ability to increase plant development by enhancing the physical characteristics (Baker, 1999) and chemical conditions (Tuffen et al. 2002; Sabrina et al. 2009a; 2011) of the soil, so they are important elements of rhizosphere ecosystem. Earthworms use the large part of organic wastes such as crop wastes, animal manure, biosolids and industrial wastes (Chan and Griffiths 1988; Hartenstein and Bisesi 1989; Edward 1998). Earthworms break up the wastes during nutrition period; they accelerate decomposition of the substances and the change of physico-chemical features of the materials (Orozco et al. 1996; Vinceslas-Akpa and Loquet 1997). Earthworms increase phosphorus availability from the soils to the plants when they are well entreated with manure $(\mathrm{P})$ that has low solubility such as phosphate rock (Ouédraogo et al. 2005).

As a phosphate source, the application of triple superphosphate and rock phosphate to two different types of soils which were neutral and acidic; and the effects of avena with dry matter rate (Avena sativa $\mathrm{L}$.) on $\mathrm{P}$, $\mathrm{Mn}, \mathrm{Fe}, \mathrm{Cu}$ and $\mathrm{Zn}$ content in different incubation period were different in the plants grown in each soil but the difference was not found significant in general. Different results were obtained depending on incubation period, phosphate sources and the soil (Erdal et al. 1998).

Rock phosphate is the source of chemical phosphorous castings but its solubility is very low, so one of the solutions to increase its effectiveness is the application of the micro organisms that dissolve phosphate. In a greenhouse study, five levels of rock phosphate that contained optimum $16 \mathrm{mg} \mathrm{kg}^{-1}(0,25,50,75$ and $100 \%$ ) were applied to three soils (low, moderate and high) in different phosphorous levels of 4 frequency and Bacillus subtilis and Pseudomonas putida were grafted. As a result of the study, it was discovered that it had the highest dry matter yield in soil $\mathrm{P}$ with maximum manure treatment of pseudomonas. The fact that the a bacterial treatments had the highest $\mathrm{P}$ uptake capacity was attributed to the secretion of toxic materials by bacteria (Hosseini et al. 2010).

\footnotetext{
*Corresponding author email: ekaraarslan@selcuk.edu.tr
} 
A study was performed on the solubility of phosphate rock obtained from two different sources to research the effects of phosphorus solvent bacteria Azospirillum brasilense $\mathrm{SP}-245$, Bacillus subtilis OSU-142, Bacillus megaterium M3, Raoultella terrigena, Burkholderia cepacia BA-7 in solution atmosphere. Research results show that bacteria applications caused a decrease in solution $\mathrm{pH}$ where both phosphorus sources were used but they caused an increase in electrical conductivity, phosphorus and $\mathrm{Ca}$ content (Güneş et al. 2013). Marie LB et al. (2018) conducted a pot-experiment with maize in a sandy loam soil with two fertilizer levels ( 0 and $100 \mathrm{mg} \mathrm{P} \mathrm{kg}^{-1)}$ and three biochars produced from soft wood $(\mathrm{SW})$, rice husk (RH) and oil seed rape (OSR). They found that biochar effects on biological and chemical $\mathrm{P}$ processes in the rhizosphere were driven by biochar properties.

In a greenhouse study performed to search the effects of earthworm, mycorrhiza and rock phosphate applications on grass and phosphorus suitability in the soil, it was discovered that earthworm castings application increased dry matter rate and $\mathrm{P}$ accumulating of the grass considerably. When $\mathrm{P}, \mathrm{N}, \mathrm{K}, \mathrm{Ca}$ and $\mathrm{Mg}$ concentration in grass was compared to the other treatments, it was seen that these values were significantly higher in the soil with earthworms and the increase in phosphorus use efficiency of the grass was attributed to earthworm, mycorrhiza and rock phosphate (Sabrina et al. 2013).

Although chemical fertilizers which are used for phosphorus sources have a productive effect in agriculture, they have an adverse impact on the sustainable use of soil. The importance of organic agriculture is increasing nowadays and the necessity of phosphate rock use is obvious. However, the low solubility of the phosphate sources applied to the soil has limited the use of them in agriculture. This study is intended to show the importance of the earthworms for the determination of the potential of phosphate rock to be used for phosphorus castings sources in agriculture and to determine the effects of the applications on the development and nutrient element content of the corn plant.

\section{Materials and Methods}

The study was carried out in the greenhouse of Selçuk University Faculty of Agriculture in the form of three

Table 1

Some physical and chemical properties of the trial soil

\begin{tabular}{llllll}
\hline Properties & Value & Properties & Value & Properties & Value \\
\hline Sand $\%$ & 21.28 & Org. Mat. $(\%)$ & 0.11 & $\mathrm{Fe}\left(\mathrm{mg} \mathrm{kg}^{-1}\right)$ & 2.25 \\
Clay $\%$ & 50.72 & $\mathrm{CaCO}_{3}(\%)$ & 21.48 & ${\mathrm{Cu}\left(\mathrm{mg} \mathrm{kg}^{-1}\right)}$ & 0.31 \\
Silt $\%$ & 28.00 & Total N $\left(\mathrm{mg} \mathrm{kg}^{-1}\right)$ & 12.00 & $\mathrm{Mn}\left(\mathrm{mg} \mathrm{kg}^{-1}\right)$ & 1.15 \\
pH & 8.15 & $\mathrm{P}_{2} \mathrm{O}_{5}\left(\mathrm{mg} \mathrm{kg}^{-1}\right)$ & 6.30 & $\mathrm{Zn}\left(\mathrm{mg} \mathrm{kg}^{-1}\right)$ & 0.37 \\
EC $(\mu \mathrm{S} / \mathrm{cm})$ & 625 & $\mathrm{~K}_{2} \mathrm{O}\left(\mathrm{mg} \mathrm{kg}^{-1}\right)$ & 26.07 & & \\
\hline
\end{tabular}

\section{Results and Discussion}

\subsection{Development of the plants}

frequency vase trial in randomized blocks, factorial experimental design. A mixture of clay soil, earthworms (Lumbricus terrestris L.) and raw rock phosphate $(15 \%)$ were used as sample in the study. $10 \mathrm{~kg}$ of oven-dried soil were put in the pots and 0-5-10-15-2025-30-35 and $40 \mathrm{~kg} \mathrm{da}^{-1}, \mathrm{P}_{2} \mathrm{O}_{5}$ application dose of raw rock phosphate was added. Testing vases were divided into two groups as with and without earthworms. Three earthworms were added to each vase containing earthworms. In the study, the seeds of 10 corns (Zea mays L.), a Pioneer corn type, were planted in the vases with $10 \mathrm{~kg}$ soil as a testing plant and this number was reduced to 6 after germination. Night and day temperature in the greenhouse was $28 / 20^{\circ} \mathrm{C}, 16$ hours' light $/ 8$ hours' dark period; and relative humidity was between $40 / 60 \%$. The plants were irrigated with distilled water and harvested by cutting from the soil surface after 50 days of development, and then some measurements and analyzes were made on the harvested plants. After the plant samples from the experiment were watered by tap water and diluted HCI solution, they were directed through pure water. Then they were dried in drying oven at $70^{\circ} \mathrm{C}$ for 48 hours and ground, and then nitrogen analysis was performed in the extract obtained by means of method of wet decomposition (Bayrakl1 1987) with sulphuric acid (Lindsay and Norwell 1978). $\mathrm{P}, \mathrm{K}, \mathrm{Ca}, \mathrm{Mg}, \mathrm{Fe}, \mathrm{Cu}, \mathrm{Mn}, \mathrm{Zn}$ elements were analyzed with ICP-AES in extracts obtained from burned plant samples (Soltanpour and Workman 1981).

The analysis of the soil sample used in the test was performed according to texture: (Bouyocous 1951), pH: (Richards 1954), EC: (U.S. Salinity Lab. Staff 1954), organic matter: (Smith and Weldon 1941), Ca$\mathrm{CO}_{3}$ : (Hizalan and Ünal 1966), total nitrogen: (Bremner 1965), phosphorus: (Olsen et al. 1954), changeable cations: (Knudsen et al. 1982), trace elements (Soltanpour and Workman 1981). Some physical and chemical characteristics of the soil used in the study were given in Table 1. Data were analyzed as a factorial experiment in a completely randomized manner with three replication using the JMP statistical software, version 5.1 (SAS Institute INc., Cary, NC, USA). Sources of variation were treatments, incubation day and their interaction. Means were compared by Student's t-test at a significance level of 0.05 .

According to the data obtained from the test, the effect of earthworm and raw rock phosphate applied to the soil on the growth of corn plant was found to be 
statistically significant $(\mathrm{p}<0.05)$. An increase in the length of the plant was observed when plants with both worms and raw rock phosphate were compared with other no-worm applications. Plant lengths in worm and raw rock phosphate application were between 64.72 and $79.78 \mathrm{~cm}$, whereas plants with raw rock phosphate were only between 52.06 and $68.52 \mathrm{~cm}$. The highest plant length was obtained from the plant which was grown in the application dose of $20 \mathrm{~kg} \mathrm{P}_{2} \mathrm{O}_{5} \mathrm{da}^{-1}(79.78$ $\mathrm{cm})$. The lowest plant length $(52.06 \mathrm{~cm})$ was obtained form the control application without earthworm (Figure 1).

The effects of earthworm casting application and raw rock phosphate applied to soil in different doses on corn biome are given in Figure 2. As shown in the figure, the effects of the application on the biomass of the corn are different and these differences were significant when the application effect was examined in terms of dose and application $\mathrm{x}$ dose interaction $(\mathrm{p}$ $<0.05$ ). The biomass values of the corn varied between 78.26 and $31.66 \mathrm{~g}$. The highest corn biomass value was obtained as $78.26 \mathrm{~g}$ from the plant where earthworms were added and the raw rock phosphate was applied as $20 \mathrm{~kg} \mathrm{P}_{2} \mathrm{O}_{5} \mathrm{da}^{-1}$. The lowest biomass value was obtained $(31.66 \mathrm{~g})$ in the control application without earthworm (Figure 2).

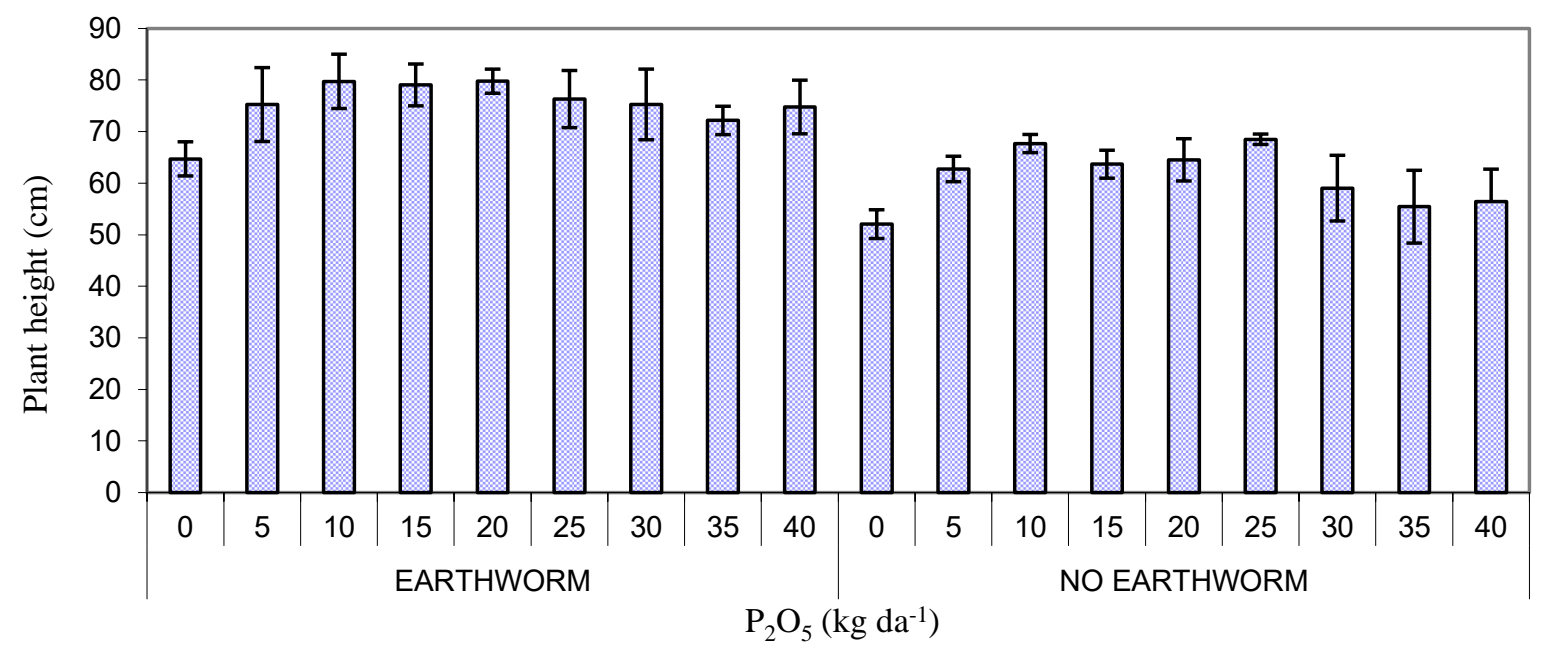

Figure 1

The effect of raw rock phosphate and earthworm application on the content of corn plant height.

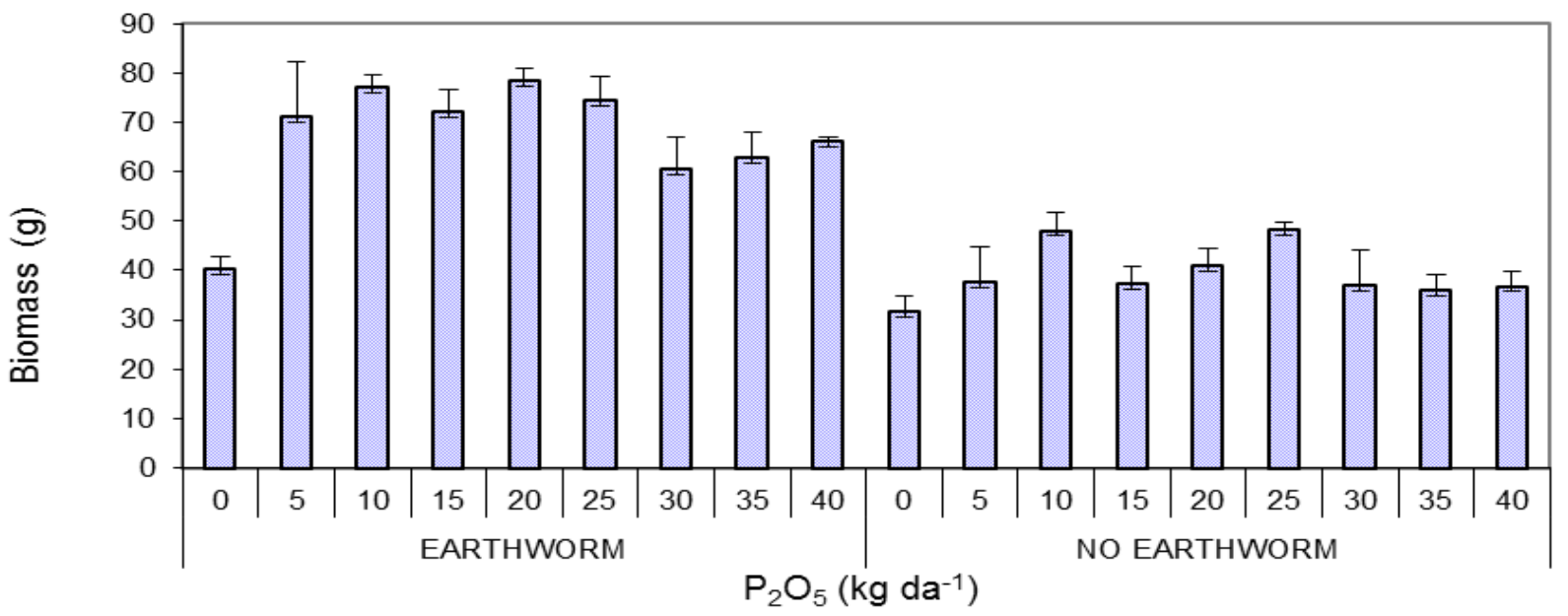

Figure 2

The effect of raw rock phosphate and earthworm application on the content of corn plant biomass.

\subsection{Macro element contents of the plants}

The effect of different levels of raw rock phosphate applications on the nitrogen content of corn is given in Table 2. The highest $\mathrm{N}$ content in corn was received from the plant with earthworms at $20 \mathrm{~kg} \mathrm{P}_{2} \mathrm{O}_{5} \mathrm{da}^{-1}$ application dose. Nitrogen content of the corn increased more than the control group and the difference between the applications (with and without earth- worms) and raw rock phosphate doses was significant. The application $\mathrm{x}$ dose interaction to the nitrogen content of the relevant plant was statistically insignificant $(p<0.05)$ (Table 2). Nitrogen content of the corn varied between 2.73 and $1.45 \%$ and the lowest nitrogen content was determined in the control application without earthworm. According to Jones et al. (1991), nitrogen contents of corn were at the fault level. 
The effects of the application of different raw rock phosphate doses and earthworm castings on phosphorus content are given in Table 2. As seen in Table 2, $\mathrm{P}$ concentration content of corn generally increased depending on the increasing phosphorus doses. The effect of two different applications (with and without worm) and different doses of raw rock phosphate on the phosphorus content of maize was found significant ( $p$ $<0.05$ ). According to Jones et al. 1991, phosphorus content of the plants is between $0.3-0.5 \%$ of their dry weight. According to the research results, phosphorus content of corn is at the fault level. This rate is in minus position and it drops below $0.1 \%$. Phosphorus content of corn changed between 0.18 and $0.38 \%$ and the highest phosphorus content was determined in 20 $\mathrm{kg} \mathrm{P}_{2} \mathrm{O}_{5} \mathrm{da}^{-1}$ application dose without earthworm $(0.38 \%)$; the lowest phosphorus content was found in the control group without earthworm $(0.18 \%)$. Phosphorus content of the test soil was quite low $(0.001 \%)$. Phosphorus level of the soils generally varies between $0.02 \%$ and $0.15 \%$ and too little of it $(1-2 \%)$ can be obtained by the plants. Phosphorus exists in the soil in two ways as organic and inorganic. The plants make use of inorganic orthophosphate that is melted in groundwater.

The effect of the applications with and without earthworm and different raw rock phosphate doses on potassium content of corn is given in Table 2. The highest $(5.04 \%) \mathrm{K}$ content in corn was obtained from the plant with earthworm in $5 \mathrm{~kg} \mathrm{P}_{2} \mathrm{O}_{5} \mathrm{da}^{-1}$ application dose. Potassium content of corn increased compared to the control group and the difference between the applications (with and without earthworm) and raw rock phosphate doses was found significant. The effect of application of $\mathrm{x}$ dose interaction to the potassium content of the plant in question was found significant (Table 2). Potassium content of corn plant varied between 3.15 and $5.04 \%$ and the lowest potassium content (3.15 $\%)$ was determined in the control application without earthworm. According to the research results, potassium content of corn plant is usually sufficient and even higher (Jones et al. 1991).

The effect of different doses of raw rock phosphate and earthworm castings application on the calcium content of corn is given in Table 2. As seen in Table 2, $\mathrm{Ca}$ concentration of corn varied depending on increasing doses of phosphorus. The effect of two different applications (with and without earthworm) and different doses of raw rock phosphate on the calcium effect of corn was found significant $(\mathrm{p}<0.05)$. According to the research results, the calcium contents of corn are generally in sufficient level (Jones et al. 1991). The highest $\mathrm{Ca}$ content in corn was obtained from the plant with earthworms at the application dose of $5 \mathrm{~kg} \mathrm{P}_{2} \mathrm{O}_{5}$ $\mathrm{da}^{-1}$.

The effect of different doses of raw rock phosphate and earthworm castings application on the magnesium content of corn is given in Table 2. The highest $\mathrm{Mg}$ content $(0.38 \%)$ in corn plant was obtained from the plant without earthworm at the application dose of 35 $\mathrm{kg} \mathrm{P}_{2} \mathrm{O}_{5} \mathrm{da}^{-1}$. Magnesium content of corn increased more than the control and the difference between the applications (with and without earthworm) and raw rock phosphate doses was found significant. The effect of application $\mathrm{x}$ dose interaction on the magnesium content of the relevant plant was not significant (Table 2 ). The magnesium content of corn plant varied between 0.29 and $0.38 \%$ at a sufficient level (Jones et al., $1991)$, and the lowest magnesium content $(0.29 \%)$ was found in the control application with earthworm. According to the research result, the magnesium content of corn plant was generally at a sufficient level (Jones et al. 1991).

\subsection{Micro element contents of the plants}

The effect of different doses of raw rock phosphate on the iron content of corn is given in Table 2. The highest $\mathrm{Fe}$ content in the corn $\left(215.11 \mathrm{mg} \mathrm{kg}^{-1}\right)$ was obtained from the plant to which the earthworm castings were added at an application dose of $25 \mathrm{~kg} \mathrm{P}_{2} \mathrm{O}_{5}$ $\mathrm{da}^{-1}$. Fe content of corn increased in comparison with the control plant and the difference between the applications (with and without earthworm) and raw rock phosphate doses, and application $\mathrm{x}$ dose interaction was found statistically significant $(\mathrm{p}<0.05)$ (Table 2). Fe content of corn varied between 215.11 and 104.56 $\mathrm{mg} \mathrm{kg}{ }^{-1}$ and the lowest Fe content was determined in the control application with earthworm. According to Jones et al. (1991), Fe content of corn was at a sufficient level.

The effect of different doses of raw rock phosphate and earthworm castings application on the copper content of corn is given in Table 2. As seen in Table 2, Cu concentration of corn varies between 9.61 and 12.33 $\mathrm{mg} \mathrm{kg}$. The effect of two different applications (with and without earthworm) and different doses of raw rock phosphate on copper content of corn was found significant $(\mathrm{p}<0.05)$. According to Jones et al. (1991), copper content of corn is at a sufficient level. The highest $\mathrm{Cu}$ content in corn was obtained from the plant $\left(12.33 \mathrm{mg} \mathrm{kg}^{-1}\right)$ that the earthworm was added to at an application dose of $20 \mathrm{~kg} \mathrm{P}_{2} \mathrm{O}_{5} \mathrm{da}^{-1}$.

The effect of the applications with and without earthworm and different doses of raw rock phosphate on the zinc content of corn is given in Table 2. The highest $\mathrm{Zn}$ content $\left(55.67 \mathrm{mg} \mathrm{kg}^{-1}\right.$ ) in corn was obtained from the plant with earthworm at $20 \mathrm{~kg} \mathrm{P}_{2} \mathrm{O}_{5} \mathrm{da}^{-}$ ${ }^{1}$ application dose. Zinc content of corn increased compared to the control and the difference between the applications (with and without earthworm) and raw rock phosphate doses was found significant $(\mathrm{p}<0.05)$. The effect of application $\mathrm{x}$ dose interaction on the zinc content of the plant in question was found significant $(\mathrm{p}<0.05)$ (Table 2). According to Jones et al. (1991), zinc contents of corn were at a sufficient level. Zinc content of corn varied between 31.44 and $55.67 \mathrm{mg} \mathrm{kg}^{-}$ ${ }^{1}$ and the lowest zinc content was determined in the control application with earthworm (31.44 $\left.\mathrm{mg} \mathrm{kg}^{-1}\right)$.

The effect of the applications with and without earthworm and different doses of raw rock manganese on the zinc content of corn is given in Table 2 . 
As seen in Table 2, Mn concentration of corn varies depending on increasing doses of phosphorus. The effect of two different applications (with and without earthworm) and different doses of raw rock phosphate on manganese content of corn was found statistically significant in terms of application, dose and application $x$ dose interaction $(\mathrm{p}<0.05)$. According to Jones et al. Table 2

The effect of raw rock phosphate and earthworm application on the content of corn plant nutrient element.

\begin{tabular}{|c|c|c|c|c|c|c|c|c|c|c|}
\hline \multirow{2}{*}{\multicolumn{2}{|c|}{$\begin{array}{l}\mathrm{P}_{2} \mathrm{O}_{5} \\
\left(\mathrm{~kg} \mathrm{da}^{-1}\right)\end{array}$}} & \multicolumn{5}{|c|}{$\%$} & \multicolumn{4}{|c|}{$\mathrm{mg} \mathrm{kg}^{-1}$} \\
\hline & & $\mathrm{N}$ & $\mathrm{P}$ & $\mathrm{K}$ & $\mathrm{Ca}$ & $\mathrm{Mg}$ & $\mathrm{Fe}$ & $\mathrm{Cu}$ & $\mathrm{Zn}$ & $\mathrm{Mn}$ \\
\hline \multirow{9}{*}{ 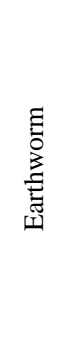 } & 0 & 1.83 & $0.20 \mathrm{fg}$ & $4.19 \mathrm{e}-\mathrm{h}$ & $0.31 \mathrm{gh}$ & 0.29 & $104.56 \mathrm{f}$ & $9.67 \mathrm{e}$ & 31.441 & $98.83 \mathrm{e}-\mathrm{g}$ \\
\hline & 5 & 2.44 & $0.25 \mathrm{~cd}$ & $5.04 \mathrm{a}$ & $0.62 \mathrm{a}$ & 0.34 & $125.56 \mathrm{ef}$ & $11.39 \mathrm{a}-\mathrm{c}$ & $47.22 b-d$ & $100.11 \mathrm{e}-\mathrm{g}$ \\
\hline & $\overline{10}$ & 2.59 & $0.24 c-f$ & $4.57 \mathrm{~b}-\mathrm{e}$ & $0.49 \mathrm{bc}$ & 0.36 & $158.67 \mathrm{~cd}$ & $11.72 \mathrm{ab}$ & $52.56 \mathrm{ab}$ & $102.22 \mathrm{~d}-\mathrm{g}$ \\
\hline & $\overline{15}$ & 2.26 & $0.24 \mathrm{c}-\mathrm{e}$ & $4.62 \mathrm{bc}$ & $0.38 \mathrm{e}-\mathrm{g}$ & 0.31 & $164.22 \mathrm{c}$ & $11.39 \mathrm{a}-\mathrm{c}$ & $49.22 \mathrm{a}-\mathrm{c}$ & $100.28 \mathrm{e}-\mathrm{g}$ \\
\hline & 20 & 2.73 & $0.26 \mathrm{~cd}$ & $4.94 \mathrm{ab}$ & $0.45 \mathrm{~b}-\mathrm{d}$ & 0.34 & $186.67 \mathrm{bc}$ & $12.33 \mathrm{a}$ & $55.67 \mathrm{a}$ & $121.28 \mathrm{a}$ \\
\hline & 25 & 2.46 & $0.23 \mathrm{c}-\mathrm{f}$ & $4.66 \mathrm{bc}$ & $0.52 \mathrm{~b}$ & 0.32 & $215.11 \mathrm{a}$ & $11.89 \mathrm{ab}$ & $45.00 \mathrm{c}-\mathrm{e}$ & $116.94 \mathrm{ab}$ \\
\hline & 30 & 2.00 & $0.30 \mathrm{~b}$ & $4.48 \mathrm{c}-\mathrm{e}$ & $0.40 \mathrm{~d}-\mathrm{f}$ & 0.36 & $173.33 \mathrm{bc}$ & $11.22 \mathrm{~b}-\mathrm{d}$ & $41.00 \mathrm{~d}-\mathrm{g}$ & $111.67 \mathrm{a}-\mathrm{d}$ \\
\hline & 35 & 2.36 & $0.25 \mathrm{~cd}$ & $4.62 \mathrm{~b}-\mathrm{d}$ & $0.47 \mathrm{bc}$ & 0.36 & $179.89 \mathrm{bc}$ & $11.00 \mathrm{~b}-\mathrm{d}$ & $41.89 \mathrm{~d}-\mathrm{g}$ & $114.72 \mathrm{a}-\mathrm{c}$ \\
\hline & $\overline{40}$ & 2.34 & $0.27 \mathrm{a}-\mathrm{c}$ & $4.22 \mathrm{~d}-\mathrm{h}$ & $0.36 \mathrm{fg}$ & 0.34 & $192.67 \mathrm{ab}$ & $11.61 \mathrm{ab}$ & $43.33 \mathrm{c}-\mathrm{f}$ & $107.11 \mathrm{~b}-\mathrm{e}$ \\
\hline \multirow{10}{*}{ 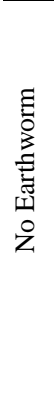 } & 0 & 1.45 & $0.18 \mathrm{~g}$ & $3.15 \mathrm{j}$ & $0.25 \mathrm{~h}$ & 0.31 & $110.89 \mathrm{ef}$ & $9.61 \mathrm{e}$ & $32.56 \mathrm{~h} 1$ & $92.56 \mathrm{~g}$ \\
\hline & 5 & 1.87 & $0.23 \mathrm{c}-\mathrm{f}$ & $4.38 \mathrm{c}-\mathrm{f}$ & $0.34 \mathrm{fg}$ & 0.29 & $127.56 \mathrm{ef}$ & $9.72 \mathrm{e}$ & $40.22 \mathrm{~d}-\mathrm{g}$ & $99.50 \mathrm{e}-\mathrm{g}$ \\
\hline & 10 & 1.75 & $0.25 \mathrm{~cd}$ & $4.34 \mathrm{c}-\mathrm{f}$ & $0.50 \mathrm{bc}$ & 0.38 & $158.56 \mathrm{~cd}$ & $10.50 \mathrm{c}-\mathrm{e}$ & $35.56 \mathrm{~g}-1$ & $106.22 \mathrm{c}-\mathrm{f}$ \\
\hline & 15 & 1.74 & $0.24 \mathrm{c}-\mathrm{e}$ & $4.47 \mathrm{c}-\mathrm{e}$ & $0.48 \mathrm{bc}$ & 0.37 & $127.56 \mathrm{ef}$ & $11.06 \mathrm{~b}-\mathrm{d}$ & $37.78 \mathrm{e}-1$ & $103.61 \mathrm{~b}-\mathrm{e}$ \\
\hline & $\overline{20}$ & 1.70 & $0.38 \mathrm{a}$ & $4.29 \mathrm{c}-\mathrm{g}$ & $0.35 \mathrm{fg}$ & 0.36 & $134.67 \mathrm{de}$ & $11.39 \mathrm{a}-\mathrm{c}$ & $48.44 \mathrm{bc}$ & $119.06 \mathrm{a}$ \\
\hline & 25 & 1.79 & $0.19 \mathrm{fg}$ & $3.87 \mathrm{~h}$ & $0.37 \mathrm{e}-\mathrm{g}$ & 0.37 & $125.22 \mathrm{ef}$ & $11.17 \mathrm{~b}-\mathrm{d}$ & 38.89 e-h & $95.33 \mathrm{fg}$ \\
\hline & 30 & 1.60 & $0.23 \mathrm{~d}-\mathrm{g}$ & $3.92 \mathrm{gh}$ & $0.41 \mathrm{~d}-\mathrm{f}$ & 0.37 & $134.00 \mathrm{~d}-\mathrm{f}$ & $11.56 \mathrm{ab}$ & 33.78 g-1 & $94.89 \mathrm{~g}$ \\
\hline & $\overline{35}$ & 1.80 & $0.25 \mathrm{c}-\mathrm{e}$ & $4.06 \mathrm{f}-\mathrm{h}$ & 0.44 c-e & 0.38 & $127.78 \mathrm{ef}$ & $11.00 \mathrm{~b}-\mathrm{d}$ & $35.33 \mathrm{~g}-1$ & $99.06 \mathrm{e}-\mathrm{g}$ \\
\hline & $\overline{40}$ & 1.66 & $0.20 \mathrm{e}-\mathrm{g}$ & 3.511 & $0.36 \mathrm{e}-\mathrm{g}$ & 0.37 & $124.11 \mathrm{ef}$ & $10.33 \mathrm{de}$ & $37.78 \mathrm{f}-1$ & $96.11 \mathrm{e}-\mathrm{g}$ \\
\hline & $\begin{array}{l}\text { LSD } \\
(0.05)\end{array}$ & ns & 0.04 & 0.35 & 0.06 & ns & 25.40 & 0.89 & 6.32 & 9.44 \\
\hline
\end{tabular}

Earthworm are known to accumulate heavy metals in their tissues. Different earthworm species accumulate heavy metals to different degrees; further, heavy metal accumulation in earthworms is also dependent on soil characteristics (including organic waste). The accumulations of Zinc and Copper in particular have higher rates of accumulation in earth worms (Domiguez et al. 2012; Lukhari et al. 2005).

The vermicomposting process results in the Potassium content being significantly increased. This is due to variations in Potassium distribution between the exchangeable and non-exchangeable forms. The total quantity of Potassium is however unchanged by earthworms - they however can change the form of Potassium in the soil which increases the nutrient content (Kumar 2005). The large part of phosphorus in the soil is in a formation that can't be made use of the plants. Phosphorus must be decomposed and turned into phosphate anions so that the plants can benefit from the phosphorus existing in organic or inorganic combinations of phosphorus.

The plants can benefit from free phosphate anions easily but it is hard for phosphate anions to be free in many kinds of soil. The plants can hardly make use of phosphorus especially in lime soil and in high $\mathrm{pH}$ soils and in too much acidic soil (Güneş et al. 2013).

When the development and nutrient element content of corn without earthworm are compared to the corn with earthworm, it was found that the inclusion of
(1991), manganese content of corn is at a sufficient level in terms of these values. The highest Mn content in corn was obtained from the plant with earthworm at $20 \mathrm{~kg} \mathrm{P}_{2} \mathrm{O}_{5} \mathrm{da}^{-1}$ application dose $\left(121.28 \mathrm{mg} \mathrm{kg}^{-1}\right)$. The lowest manganese content was obtained from the control application without earthworm $\left(92.56 \mathrm{mg} \mathrm{kg}^{-1}\right)$. the earthworm increased the solubility of the phosphorus introduced into the soil and again increased the growth and nutrient content of the plant. In terms of qualitative and quantitative metabolic compositions, the properties of the rhizosphere differ from those of bulk soil, and their roles should be taken into account when investigating root exudates (Haichar et al. 2014; Mönchgesang et al. 2016; Coskun et al. 2017). Studies have shown that the inclusion of worm and raw rock phosphate significantly improves the growth and nutrient content of plants. (Erdal et al. 1998; Sabrina et al. 2013; Quédraogo et al. 2005; Hosseini et al. 2010; Güneş et al. 2013). There may be some reasons for increased phosphorus solubility, plant growth and nutrient content as a result of the earthworm inclusion. Earthworms are generally called as ecosystem engineers because of their abilites to modify the soils and plant communities (Lavelle et al. 1997; Edwards, 1998; Hale et al. 2005). Earthworms change the physical characteristics (Edwards and Shpitalo 1998), nutrition (Edwards and Bohlen 1996) and biological activities of the soil (Doube and Brown 1998) and surface plant communities (Piearce et al. 1994; Wurst et al. 2005) on account of mixing the surface, droppings, canalising and other activities. Zhu et al. (2016) also reported that the sugar content in corn root exudates increased especially as the $\mathrm{N}$ rate increased.

According to the results of this study, earthworm castings application and raw rock phosphate generally increased the development and nutrient element content 
of corn. Earthworm castings application and raw rock phosphate increased the development and nutrient content of the plants in other similar studies as well (Erdal et al. 1998; Sabrina et al. 2013). This contribution of the earthworms can be attributed to their digestion of organic matters in a good way. Accordingly, in a study performed in California it was discovered that surface litter was decomposed faster after Lumbricus terrestris was put in an apple garden that was irrigated and the soil became more fertile (Werner 1997). Plants need small quantities of trace elements (or Micronutrients) in the soil to thrive. If the quantity of Micronutrients is however to large, this can prevent plants from thriving or even be harmful (Khwairakpam and Bhargava 2009). Earthworms are helpful in this regard due to their ability to accumulate certain metals ingested or absorbed via their intenstive and skin. This can help regulate potentially harmful elements to plants in the soil (Sharma et al. 2005).

Phosphorus solubility has increased due to the earthworm casting applications being applied as an increasing factor for the current usefulness of phosphate sources. In worm and nonworm applications, the usefulness of phosphorus has increased more than control application (Table 2). Similar studies on this subject support this research (Ouédraogo et al. 2005; Hosseini et al. 2010).

The success of earthworms in how they can digest organic matter in the soil is evident in the excellence of their castings. Tutar (2013) stated that earthworm castings contained a large amount of bacteria (azotobacter) and mycorrhizal mushrooms that produce nitrogen fixation from symbiotic bacteria (Rhizobium) and asymbiotic microorganisms. He emphasized that secretion of the earthworms contained a large amount of and a great variety of enzymes. When vitamins, amino acids, growth hormone, and these secretions mixed with their feces, it allowed the plant to grow faster and made it more resistant to bad environmental conditions.

\section{Conclusion}

It is important to understand the interdependency between the soil, earthworms, metals and microorganisms in the soil and vermicomposts. Understanding these dependencies is key to creating high quality organic fertilizers. Microorganisms in the soil are a key food source for earthworms, but earthworms cannot digest some microorganism species; in such cases, their population can increase in the earthworm's gut and in their excrement. On the other hand, earthworms can kill some microorganism species during digestion.

This study was intended to be able to increase current resoluble phosphorus amount and the usability of raw rock phosphate in agriculture. The importance of organic agriculture is increasing nowadays and the necessity of phosphate rock use becomes obvious. Low solubility of these phosphate sources limits their uses in agriculture. Actually, the use of natural sources in natural ways without damaging the structure of the soil is imporant in agricultural sustainability. When this was taken into consideration, it was found out as a result of the study that the earthworms applied to increase the solubility of the existing phosphorus and raw rock phosphate in the soil made a contribution to the solubility considerably. Therefore, instead of giving more manure to lime soils to compensate for phosphorus deficiency due to fixing, the solubility of the currently applied fertilizer should be increased. In these applications, making use of earthworms, which are completely natural and biological fertilizers, not only contributes greatly to the sustainability of the soil but also prevents extra costs. If there is a production with manure application from the beginning, it would be wise to do this with phosphorus rock.

\section{References}

Baker, GH (1999). Spatial and temporal pattern in the abundance and biomass of earthworm populations in pastures in Southern Australia. Pedobiologia 43: 487-496.

Bayraklı F (1987). Soil and Plant Analysis (Translation and Review). 19 Mayls University Faculty of Agriculture Pub.:17, Samsun.

Bremner JM (1965). Methods of Soil Analysis Part 2. Chemical and Microbiological Properties. Ed. A.C.A. Black Amer. Soc. of Agron Inc. Pub. Agron. Series No: 9 Madison USA.

Bouyoucos CA (1951). Hidrometer Method Improved for Making Particle Size. Analysis of Soil Agron J. 54 (5). 464-465.

Chan PLS, Griffiths DA (1988). The vermicomposting of pre-treated pig manure. Biol Waste. 24: 57-69.

Coskun D, Britto DT, Shi WM, Kronzucker HJ (2017). How plant root exudates shape the nitrogen cycle. Trends Plant Sci. 22: 661-673.

Domínguez-Crespo MA, Sánchez-Hernández ZE, TorresHuerta AM, Negrete-Rodríguez MLX, Conde-Barajas E, Flores-Vela A (2012). Effects of the heavy metals $\mathrm{Cu}, \mathrm{Ni}$, $\mathrm{Cd}$ and $\mathrm{Zn}$ on the growth and reproduction of epigeice earthworms (E.fetida) during the vermistabilization of municipal sewage sludge. Water Air Soil Pollut. 223: 915-931.

Doube BM, Brown GG (1998). Life in a complex community:functional interactions between earthworms. organic matter. microorganism and plants. In: Edwards. C.A. (Ed.). Earthworm Ecology. CRC Press. Boca Raton. FL. pp. 179-211.

Edwards CA, Bohlen PJ (1996). Biology and Ecology of Earthworms. Third ed. Chapman\&Hall. London. UK. pp.426.

Edwards CA (1998). The use of earthworms in the breakdown and management of organic wastes. In: Edwards CA (ed) Eartworm Ecology. CRC Press. Boca Raton. FL. USA. p 327-354.

Edwards WM, Shpitalo MJ (1998). Consequences of earthworms in agricultural soils: aggregation and porosity. In: Edwards. C.A.(Ed.). Earthworm Ecology. CRC press. Boca Raton. FL. pp. 147-161.

Erdal İ, Samet H, Alpaslan M, Taban S (1998). Effect of triple super phosphate and rock phosphate as phosphorus source in different incubation periods on the amount of dry matter and $\mathrm{P}, \mathrm{Mn}, \mathrm{Fe}, \mathrm{Cu}$ and $\mathrm{Zn}$ content of oat plant (Avena sativa L.). Yüzüncü Yll University Faculty of Agriculture, Journal of Agri. Sci. 17-21. 
Gahoonia TS, Nielsen EN, Ole BL (1999). "Phosphorus (P) acquisition of cerea fertilization". Plant and Soil 211: 269-281.

Güneş A, Turan M, Güllüce M, Şahin F, Karaman MR (2013). The Effect of Different Bacterial Applications on the Resolution of Rock Phosphate. Soil Water Journal 2(1): 53-61.

Haichar FE, Santaella C, Heulin T, Achouak W (2014). Root exudates mediated interactions below ground. Soil Biol Biochem. 77: 69-80.

Hale CM, Frelich LE, Reich PB, Pastor J (2005). Effects of European earthworm invasion on soil characteristics in northern hardwood forests of Minnesota USA. Ecosystems 8: 911-927.

Hartenstein R, Bisesi MS (1989). Use of Earthworm Biotechnology for the Management of Effluents from Intensively Housed Livestock. Outlook on Agriculture, USA, 18: 72-76.

Hizalan E, Ünal H (1966). Soil chemical analysis. University of Ankara Agriculture Faculty Publics. 273. Ankara.

Hosseini HM, Khayami S, Besharati H, Bybordi S (2010). Study of the effects of rock phosphate application with phosphate solublizing bacteria on P availability for corn. 19th World Congress of Soil Science. Soil Solutions for a Changig World. Brisbane. Australia. 261-263.

Jones Jr. JB, Wolf B, Mills HA (1991). Plant Analysis Handbook. A Practical Sampling. Preparation. Analysis. and Interpretation Guide. Micro-Macro Publishing Inc. Athens. Georgia. USA.

Khwairakpam M, Bhargava R (2009). Bioconversion of filter mud using vermicomposting employing two exotic and one local earthworm species. Bioresour Technol. 100: 5846-5852.

Knudsen DG, Peterson A, Pratt PF (1982). Lithium. sodium and potassium. In: Page AL. editor. Methods Soil Analysis. Part 2. Agronomy Monograph 9. Madison. WI. U.S.A. ASA and SSSA. p.247-262.

Köleli N, Kantar Ç (2005). Phosphate rock phosphoric acid and toxic heavy metal (Cd. Pb. Ni. As) concentration in phosphorus fertilizers. Ecology 55: 1-5.

Kumar A (2005). Verms and Vermitechnology. APH, NewDelhi.

Lavelle P, Bignell D, Lepage M, Wolters V, Roger P, Ineson P, Heal OW, Dhillion S (1997). Soil function in a changing World: the role of invertebrate ecosystem engineers. Eur. J. Soil Biol. 33: 159-193.

Lindsay WL, Norvell WA (1978). Development of DTPA soil test for zinc iron manganese and copper. Soil Sci. Soc. Am. J. 42: 421-428.

Lukhari T, Aatsinki M, Väisänen A, Haimi J (2005). Toxicity of copper and zinc assessed with three different earthworms tests. Appl Soil Ecol. 30:133-146.

Marie LB, Joseph OE, Dorette SM, Stöver FL (2018). Effect of different biochars on phosphorus $(\mathrm{P})$ dynamics in the rhizosphere of Zea mays L. Plant Soil 431: 1-2, pp.257272.

Mönchgesang S, Strehmel N, Schmidt S, Westphal L, Taruttis F, Müller E, Herklotz S, Neumann S, Scheel D (2016). Natural variation of root exudates in Arabidopsis thaliana-linking metabolomic and genomic data. Sci Rep. 6: 29033.
Olsen SR, Cole CW, Watanabe SS, Dean LA (1954). Estimation of available phosphorus in soil by extraction by sodium bicarbonate. USDA Agric. Circ. 939.19p.

Orozco FH, Cegarra J, Trujillo LM, Roig A (1996). Vermicomposting of coffee pulp using the earthworm $\mathrm{Ei}$ senia fetida: effects on $\mathrm{C}$ and $\mathrm{N}$ contents and the availability of nutrients. Biol Fert Soils. 22: 162-166.

Ouédraogo E, Lijbert B, Abdoulaye M, Leo S (2005). Organic resources and earthworms affect phosphorus availability to sorghum after phosphate rock addition in semiarid West Africa. Biol Fert Soils. 41: 458-465.

Piearce TG, Roggero N, Tipping R (1994). Earthworms and seeds. J. Biol. Educ. 28: 195-202.

Richards LA (1954). Diagnosis and Improvement of Saline and Alkali Soils. Dept. Of Agriculture. No: 60. Washington. D.C.

Sabrina DT, Hanafi MM, Nor Azwady AA, Mahmud TMM (2009). Vermicomposting of oil palm empty fruit bunch and its potential in supplying of nutrients for crop growth. Compost Sci. Util. 17: 61-67.

Sabrina DT, Hanafi MM, Nor Azwady AA, Mahmud TMM (2011). Evaluation of nutrients released from phosphorus enriched empty oil palm fruit bunches as growing media using Setaria splendida. Compost Sci. Util. 19: 61-68.

Sabrina DT, Hanafi MM, Gandahi AW, Mohamed MTM, Aziz NAA (2013). Effects of earthworms. arbuscular mycorrhizae and phosphate rock on seteria grass (Setaria splendida) and phosphorus availability in soil. Australian Journal of Crop Science 7(13): 2136-2144.

Sharma S, Pradhan K, Satya S, Vasudevan P (2005). Potentiality of earthworms for waste management and in other uses: A review. J. Am Sci. 1: 4-16.

Smith HW, Weldon MD (1941). A comparasion of some methods for the determination of soil organic matter. Soils Sci. Soc. Amer. Proc. 5: 177-182.

Soltanpour PN, Workman SM (1981). Use of InductivelyCoupled Plasma Spectroscopy for the Simultaneous Determination of Macro and Micro Nutrients in $\mathrm{NH}_{4} \mathrm{HCO}_{3}-$ DTPA Extracts of Soils. Developments in Atomic Plasma Analysis. In: Barnes R.M. (ed). USA. 673-680.

Tutar U (2013). Investigation of the Antimicrobial Activity of Vermicompost Obtained from Soil Worms on Some Plant Pathogens. Cumhuriyet Science Journal 34(2): 1-12.

Tuffen F, Eason WR, Scullion J (2002). The effect of earthworms and arbascular mycorrhiza fungi on growth of and ${ }^{32} \mathrm{P}$ transfer between Allium porrum plants. Soil Biol. Biochem. 34: 1027-1036.

US Salinity Lab Staff (1954). Diagnosis and improvement of saline and alkali soils. U.S. Goverment Handbook No: 60. Printing Office. Washington.

Werner M (1997). Earthworm team up with yard trimmings in orchards. Biocycle 38(6): 64-5.

Wurst S, Langel R, Scheu S (2005). Do endogeic earthworm change plant compettion? Microcosm Study. Plant Soil 271: 123-130.

Vinceslas-Akpa M, Loquet M (1997). 13C CPMAS NMR spectroscopy of organic matter transformation in lignocellulosic waste products composted and vermicomposted (Eisenia fetida andrei). Eur J Soil Biol. 30: 17-28.

Zhu SS, Vivanco JM, Manter DK (2016). Nitrogen fertilizer rate affects root exudation, the rhizosphere microbiome and nitrogen-use-efficiency of maize. Appl Soil Ecol. 107: 324-333. 